\title{
THE ROLE OF SOCIAL AND PROFESSIONAL ADAPTATION AT VOCATIONAL GUIDANCE OF HIGH SCHOOL PUPILS OF THE SECONDARY SCHOOLS IN UKRAINE
}

\author{
Tetiana Ananko \\ Postgraduate student \\ Department of social pedagogy \\ T. H. Shevchenko Chernihiv National Pedagogical University \\ 53 Hetman Polubotko str., Chernihiv, Ukraine, 14013 \\ ltat.anancko@yandex.ua
}

\begin{abstract}
The essence and types of socio-professional adaptation of pupil youth as to the choice of future professional activity were elucidated in the article. The scientific-pedagogical literature that considers the socio-professional adaptation from the different positions was analyzed. The stages of socio-professional adaptation and their role in vocational guidance of high-school pupils of the secondary educational institutions of Ukraine were characterized. The factors, criteria and parameters that influence the choice of professional activity by the pupils were elucidated. The special attention was paid to the motives of professional choice, to the interests and inclinations of high-school pupils in the process of vocational guidance of secondary educational institutions of Ukraine. The author concentrates attention on the main forms of socio-professional adaptation and scientifically grounds pedagogical conditions of vocational guidance of pupils of the higher school for the support of effective educational process. The attention is paid to the important aspects of socio-professional adaptation, conditioned by the inclusion of pupils in the complicated system of socio-productive activity. The main principles of socio-professional adaptation of pupils that favor the elaboration of individual style of the work with pupils that motivates them to the correct choice of future profession. The accent is also made on the factors of socio-professional adaptation that motivate pupils to the formation of individual style of activity at choosing profession. The subject fields and functions that are the specific professional area and play an important role in the process of vocational guidance of pupils of high school as to socio-professional adaptation to the future profession were analyzed.

Keywords: professional adaptation; social and professional adaptation; product adaptation; individual style of activities; training; social activity.
\end{abstract}

\section{Introduction}

The relevance of social and professional adaptation is maintaining and further development of professional skills to specific activities is carried out in the unity of the social activity and provides the conditions for students to entry to the educational process, and later to the labor process. On the one hand, it means the introduction of students to the new social environment (person's adaptation to work), that is the process of learning the rules and traditions adopted by the company, the process of training and retraining, awareness of what is important at the enterprise or workplace. On the other hand, adaptation - "is adapting of high school pupils to the conditions, needs and norms of behavior (work adaptation of a person)" [1].

In terms of pedagogy, sense of social and professional adaptation is that all new pupils are absorbed in a certain rhythm and consistency that has both general and individual-typological characteristics [2].

The current unstable socio-economic situation and corresponding changes in the labor market promote professional self determination of youth. Due to these circumstances the awareness of professional future direction should take place by the end of the graduation.

Nowadays every society of the world faces the challenge to overcome the negative social, economic and cultural situations successfully. The positive solution is associated with the formation of high level of professional mobility, moral certainty and stability, maximum using of abilities of students to ensure the correct choice of profession.

\section{Analysis of recent research and publications}

The problems of socio-professional adaptation in the system of secondary education of Ukraine are considered in the works of the native authors $[2,3]$, who elucidated the essence and 
conditions of vocational guidance of pupils of the high school and the factors of influence of social environment on the choice of professional activity.

The author [3] separates socio-professional adaptation that provides the purposeful formation of certain system of knowledge, abilities, value orientations and skills, necessary for entering in the labor life in pupils at the general and labor training.

In the works of the authors $[4,5]$ the essence of the notion "adaptation" was investigated. It is understood as adjustment of the person to the life in society with own needs, motives and interests according to the requirement of this society.

The authors $[5,6]$ elucidate the notion "professional adaptation" as the process of personal adjustment to the professional activity and its conditions; attainment of the plan labor productivity and correspondence between professional intentions, interests, qualities of pupils and requirements of activity.

Among the scientists it is expedient to separate the work [5], devoted to professional adaptation that is defined as social notion and also as the active process of involvement of the pupils in production, new social environment, working conditions and features of concrete profession.

The analysis of social and educational literature indicates that various scholars interpret adaptation as a process of adaptation of individual (personal) skills of human activity in the changed circumstances of exist, such as: "The process of active interaction between the individual and the environment; Adaptation is seen as a process that is holistic response to the complex changes of the individual life and work; Adaptation is seen as a process and the result of active adaptation to individual conditions of the new social environment" [6].

\section{Emphasis of unsolved aspects of the problem}

After analyzing the scientific and educational literature it should be noted that a holistic solution of the problem of adaptation does not exist. The problem of creating socio-pedagogical conditions of activation of adaptation's process of high school students in the general secondary education belongs to unresolved questions of this issue.

\section{The purpose and objective of the research}

The aim of this research is determination and scientific grounding of the role and essence of socio-professional adaptation at vocational guidance of the high-school pupils of the general educational institutions of Ukraine.

For attaining the aim the following tasks must be carried out:

1. To provide theoretical-methodological grounding of socio-professional adaptation of pupils under conditions of educational process at the secondary educational institutions of Ukraine.

2. To study the types and factors of socio-professional adaptation of pupils of the high school at the secondary educational institutions of Ukraine.

3. To reveal the criteria of socio-professional adaptation of pupils.

\section{Presentation of the main material}

The concept of "adaptation" is universal. It reflects general property of living matter to adapt to environmental changes. So, social and professional adaptation (also called production adaptation) - is a gradual adaptation of active youth to the conditions of professional training or professional work, including a young man to the working activity [7].

This process is characterized, on the one hand, by the transference of the experience of previous generations of workers to young professional people, on the other - "externalization" of previously obtained knowledge that escorted them into practice. Thus, adaptation is manifested not only in the adaptation of young specialists to the new conditions of employment, but also in the willingness to work, in the way of activities that allows master the profession.

In the social-professional adaptation there are two aspects: professional, social and psychological adaptation. Professional adaptation of high school students is the inclusion of the individuality in a complex system of social and productive activities. The objective side is exchange of activities based on the division of labor, because it includes the process of professional training and work experience. This process is very complex, and among the factors influencing it the special 
place belongs to the conscious choice of profession and high school students' following attitude to it, which is formed long before the occupation. Important role in this process is played to the motives of choice of profession, especially those associated with professional interest and inclination, as a positive attitude to the profession and the satisfaction of their work. The quality of vocational training also affects the success of the process of professional adaptation [7].

Social-psychological adaptation of students is associated with the process of inclusion in a complex system of interpersonal relations in the group, accepting existing group norms by the individual. Person enters in social psychological contacts considering personal attitude to the world, with character that has emerged. Adapting to others means to overcome themselves. This process is related to the restructuring behavior of the structure, the formation of the young specialist's respective orientations. The adaptation is always associated with adapting to something new, restructuring of old habits, stereotypes, the need to get used to new people with knowledge of new goals and objectives of the labor. It requires the young man's moral and physiological effort, due to properly organized professional education at school [7].

Professional adaptation is an active process of adaptation of students to a new social situation and the specific features of specialty. The success of professional adaptation is one of the main criteria for choosing the right profession, assessing the effectiveness of the entire vocational guidance of high school students.

Professional adaptation is carried out gradually; it is subjected to certain logic and a certain sequence. The structure of professional adaptation entails the following stages: pre-professional training, professional training, and independent professional activity. The ultimate goal of the process is ensuring conditions of harmonious combination of the interests of high school students and the interests of production, allowing pupils to enjoy work and increase its performance [2].

Professional adaptation is associated with professional advice and includes obtaining the necessary skills, the ability to quickly navigate to different productive situations to control and program their actions. Career guidance should be based on clear scientific data on reasonable professional features, its requirements to the characteristics of students.

Successful professional adaptation is characterized by the preservation and further development of skills of a particular profession. Professional adaptation is in the unity with the social adaptation and its main task is providing of conditions for a gradual "entrance" of students in educational process and later in the labor process [5]. The main ways of adaptation as an active adaptation of youth to the demands of working activity are considered as training, education, addiction, selection and formation of individual style.

Professional adaptation affects the efficient use of human resources, personal development.

Bodrov V. A. identifies a number of stages in the formation of professional competence:

- labor education and training;

- professional orientation;

- professional selection;

- professional training;

- professional adaptation;

- professional activity;

- professional certification;

- vocational rehabilitation [1].

"Professional adaptation - is a comprehensive system of measures, it is designed to facilitate the process of adaptation to the individual psychological and technical organizational features of professional activities at the workplace, a new social environment, working conditions, successful professional development of a worker" [8].

Successful professional adaptation is one of the main criteria for choosing the right profession, evaluation of the effectiveness of all career guidance. Successful professional adaptation is characterized by the preservation and further development of slopes of a particular professional activity, matching the social and personal motivation.

Professional adaptation as a social concept is defined as a process of active involvement of students in the new social environment, conditions and features of a particular profession [2]. 
As a structural component of career guidance, professional adaptation is characterized by further refining of knowledge, skills, and formation of professional qualities which high school students are required.

Professional adaptation is in the unity of the social and psychological adaptation. Socio-psychological adaptation is the adaptation of the young man to the rules of conduct in a particular professional group. It includes familiarity with the aims and objectives of the team, its traditions, attitudes and criteria of evaluation of activity.

In the process of adapting to the team, there are three stages:

- "familiarization with the new situation;

- the stage of adaptation - young person reorients, recognizes the main elements of the new system of values (for example, new rules regulations), but retains much as the equivalent of their previous settings;

- the stage of assimilation - full adaptation to the team, the settings of assimilation"[3].

Social and professional adaptation is an essential step in the process of professional self-determination of senior pupils. At this stage the shortcomings of the previous vocational guidance and training are revealed, the process of forming new attitudes, needs and interests at work and finally life plans is realized. Therefore, adaptation is a kind of criterion of efficiency of vocational guidance of pupils.

Social and professional adaptation contributes to the further strengthening of students in their professional choice. However, it discovers shortcomings of previous work with professional self of high school students and activates the formation of new plans, needs, values, interests and professional orientation of the young man at work [8].

Therefore, adaptation (translated from Latin means "adjustment") is a kind of criterion of efficiency of pupils' vocational guidance.

Preparing young people for effective inclusion in future social and professional activities is solved by secondary school in socio-professional orientation. This process involves directing youth in social and professional relationships, taking into account the relationship stages of development and age features, formation of competencies for their own conscious choice of profession.

The process of social and professional adaptation can be divided into several phases: initial adaptation, the period of stabilization, possible exclusion, re-adaptation, adaptive reduction of age capacity [4].

The first stage serves to original adaptation when young student gets used to its new social role of "employee". The next important step for young professionals is the organizational adaptation, which is understood as the adjustment of high school students for the regime of work and rest, labor regulations, entrance into the labor collective rhythm, awareness of the requirements of labor discipline. This stage of adaptation takes place in parallel with the primary adaptation, but includes a wider range of external conventions, which should accommodate students.

The next step in the professional adaptation is an industrial adaptation. At this stage, the young student learns the technological features of the work that will be performed by him, deepens his knowledge and professional skills.

This frequency of adaptation process is related to the primary criteria which were formulated by Berezin F. B.:

- "the success of the (performance of labor tasks, increasing qualifications, interaction with team members and others that affect professional performance);

- ability to prevent situations that threaten the labor process, and effectively address the threat that arose (prevention of injuries, accidents);

- realization of activity without violating physical health; satisfaction of students with the results of the process;

- satisfaction of high school students with relationships in a team [2].

This process can also be divided into two periods: pre-production (at school, college, university) and industrial (directly at work).

Among the factors which are influencing the social and professional adaptation the special place is occupied by the career choices of high school students and the subsequent attitude to them. 
School-aged children with persistent professional orientation adapts quickly to new social and industrial conditions.

Rusalynova A. shows that a stable professional orientation of students depends on many motives of choice of the profession (financial interest, attitude to the social significance of their profession) [6].

One of the indicators of social and professional adaptation of students is a social activity, which largely determines the efficiency of labor and general activity [6]. The criterion of social and professional adaptation, together with social activity, is the ability of high school students to be in positive relationships with friends and team.

The main forms of social and professional adaptation are the following:

- "passing manufacturing practices at the company, in an organization where students will work in the future;

- public events which are associated with the choice of profession;

- skill competitions among students" [6].

Also important forms of social and professional adaptation are professional consultative office, human resources department and department of technical education [6].

Social and professional adaptation of students will be successful if it is based on general principles:

1. "The principle of equal opportunities and consistency, the establishment of requirements for the future applicant for a position, if there are several candidates, then a mode sets.

2. The principle of utilization, the employees of the organization are encouraged in the first turn to fill vacancies of the qualified job, it expands opportunities of qualification growth" [6].

In the process of social and professional adaptation, such methods as conversation, power of attorney, exercise, labor task, submission of claims for work are widely used. Professional adaptation is also associated with the development of the professional career of young men and the individual style of activity.

Adapting to the future professional activity students should develop their own style of work that will achieve certain results in their chosen careers, compensating with individual characteristics everything that hinders the achievement of success or has a negative impact on career choices.

"Considering the individual style of activity we can describe stable individually specific system of psychic tools, techniques, skills, methods and ways of implementation of work, including professional" [2].

Personalization allows students, from different individual properties, different structure of abilities, temperament and character, to achieve certain results in the same profession in different ways, thus compensating with individual characteristics everything that hinders the achievement of success or negatively affects the efficiency of occupational choice.

Yovaysha L. A. identified the following factors that influence the formation of individual style, dynamic entrance in job and level of fatigue, the amount of mental work, the level of nervous tension [2].

Therefore, we can say that the individual style of activity is closely associated with inclinations, abilities and professional adaptation of high school students. So, we can identify common features, namely a stable system of techniques and methods, predestination of certain personal qualities of the system as a way to adapt to the situation effectively.

\section{Conclusions and proposals}

Professional adaptation is in the unity with social life and its main task is providing the conditions for a gradual "entrance" of students in the educational process and later in the process of employment. However, this issue needs further study and research.

As for the role of social and professional adaptation of vocational work with students of high school in general educational institutions of Ukraine, it may be noted that the socio-professional adaptation as one of the main areas of vocational work is leading to self-knowledge of high school students that is essential at conscious choice of profession, formation of motivation to a certain professional activity, stimulation and activation of internal forces of youth to develop their potential possibilities and achieve this goal. 
Consequently, social-professional adaptation plays an important role in the development of students on their professional path.

It must be noted, that the social and professional adaptation of senior pupils of secondary schools in Ukraine becomes effective with the implementation of effective career guidance, an efficient psychological and pedagogical support of students, taking into account characteristics of professional adaptation, promoting full creative development of the young learner.

Further areas of research are the pedagogical development content and tools for work with high school students as for training and social, professional adaptation of students to different kinds of industrial areas. In particular, it should continue to study the optimal social and pedagogical ways and methods of career growth, professional development and training of students who are successfully adapted to the new conditions of life and work in connection with the change of regime, the scope and difficulty in choosing their own profession.

\section{References}

[1] Baranovskij, A. B. G. M., Potapenko, G. V., Shhekin (1991). Sistema metodov professional'noj orientacii. Osnovy professional'noj orientacii. Kyiv, 164.

[2] Goncharova, N. O. (2010). Osnovy profesijnoyi oriyentaciyi. Ktiv: «Slovo», 168.

[3] Zaharov, N. N. (1989). Professional'naja orientacija shkol'nikov. Moscow: Prosveshhenie, 164.

[4] Kudrjavcev, T. V., Shegurova, V. Ju. (1998). Psihologicheskij analiz dinamiki professional'nogo samoopredelenija lichnosti. Voprosy psihologii, 2, 51-59.

[5] Uruskyj, V. (2010). Profesijna oriyentaciya uchnivskoyi molodi. Dyrektor shkoly, 38-39, 3-44.

[6] Yanczur, M. S. (2012). Profesijna oriyentaciya i metodyka profesijnoyi roboty. Kyiv: Slovo, 464.

[7] Borysenko, M. I. (2009). Profesijna oriyentaciya ta profesijnyj dobir. Chernigiv: Chernigivskyj derzhavnyj instytut prava, socialnyh tehnologij ta praci, 204.

[8] Vitkovska, O. I. (1998). Profesijne samovyznachennya yak zhyttyeva problema osobystosti. Pedagogika ta psyhologiya, 3, 171-179. 